\title{
Genetics insight into the amyotrophic lateral sclerosis/frontotemporal dementia spectrum
}

\author{
Ai-Ling Ji, ${ }^{1}$ Xia Zhang, ${ }^{2,3,4,5}$ Wei-Wei Chen, ${ }^{2,3,4,5}$ Wen-Juan Huang ${ }^{2,3,4,5}$
}

'Department of Neurology, The Third People Hospital of Xuzhou, Xuzhou, China

${ }^{2}$ Department of Neurology, Xuzhou Central Hospital,

Xuzhou, China

${ }^{3}$ The Affiliated Xuzhou Hospital of Medical College of Southeast University, Xuzhou, China ${ }^{4}$ Xuzhou Clinical School of Xuzhou Medical College,

Xuzhou, China

${ }^{5}$ Xuzhou Clinical Medical College of Nanjing University of Chinese Medicine, Xuzhou, China

Correspondence to Dr Wen-Juan Huang, Department of Neurology, Xuzhou Central Hospital, Xuzhou 221009, China; ftmlb8556215@163.com

Received 07 September 2016 Revised 28 November 2016 Accepted 29 November 2016 Published Online First 12 January 2017
CrossMark

To cite: Ji A-L, Zhang $X$, Chen W-W, et al. J Med Genet 2017:54:145-154.

\section{ABSTRACT}

Recent genetic discoveries have dramatically changed our understanding of two major neurodegenerative conditions. Amyotrophic lateral sclerosis (ALS) and frontotemporal dementia (FTD) are common, devastating diseases of the brain. For decades, ALS and FTD were classified as movement and cognitive disorders, respectively, due to their distinct clinical phenotypes. The recent identification of chromosome 9 open reading frame 72 (C9orf72) as the major gene causative of familial forms of ALS and FTD uncovered a new reality of a continuous FTD/ALS spectrum. The finding that up to $50 \%$ of all patients present some degree of ALS and FTD phenotypes supports this ALS/FTD continuum. Now $>100$ genes are known to contribute to ALS/FTD, with a few major contributors that are reviewed below. The low penetrance of C9orf72 mutations, its contribution to sporadic cases, and its combination with other genes support an oligogenic model where two or more genes contribute to disease risk, onset, progression and phenotype: from 'pure' ALS or FTD to combined ALS/ FTD. These advances in the genetics of ALS/FTD will soon lead to a better mechanistic understanding of the pathobiology of the disease, which should result in the development of effective therapies in the near future.

\section{INTRODUCTION}

Amyotrophic lateral sclerosis (ALS) and frontotemporal dementia (FTD) are devastating neurological conditions with midlife onset and no cure. ALS and FTD where initially described in the mid-to-late 1800 s as pure movement and cognitive disorders, respectively, a distinction that has continued until recently. ALS is a common neurodegenerative condition affecting motor neurons with rapid progression. ${ }^{1}$ FTD is the most common form of dementia after Alzheimer's disease (AD) and is characterised by progressive degeneration of the frontal and temporal cortex. ${ }^{2}$ The ALS and FTD clinical entities remained separated from their original descriptions, although a few studies recognised heterogeneous phenotypes in ALS that included cognitive impairment overlapping FTD. These studies were sidelined for decades in favour of a more homogenous diagnosis for classic ALS that placed the complex cases into subcategories, exceptions and dual diagnoses.

This view of ALS and FTD as independent clinical entities has changed dramatically in the last few years due to exciting advances in genetics. With the completion of the human genome in 2000, sequencing technologies have continued to improve in accuracy, speed and cost, enabling the analysis of larger populations. The identification of hexarepeat expansions in chromosome 9 open reading frame
72 (C9orf72) as the cause of the most common inherited form of ALS in 2011 explained most of the unknown genetic risk in ALS and uncovered a strong connection with FTD. ${ }^{3} 4$ Mutant C9orf72 accounts for $30 \%-50 \%$ of familial ALS, around $25 \%$ of familial FTD and a small fraction of sporadic ALS and FTD ( 5\% each) $)^{5} 6$ indicating that C9orf72 is the major genetic factor in both conditions. Once this strong genetic connection between ALS and FTD was uncovered, the careful re-evaluation of clinical descriptions recognised the existence of mixed ALS/FTD pathologies that could account for a disease spectrum. ${ }^{7} 8$ Other genes as well as protein pathology further connect ALS and FTD, including TAR DNA-binding protein-43 (TDP-43), fused in sarcoma (FUS) and sequestrome-1 (SQSTM1), among others. Although these genes with autosomal dominant effect have received the most attention in the last few years, a significant portion of sporadic ALS can be explained by a polygenic genetic contribution. Genome-wide association studies have revealed around 100 genetic loci that predispose to ALS with low penetrance and minor contribution to disease for each individual gene. ${ }^{2} 9$ Unfortunately, few of these genes have been validated in other studies and, thus, their role in ALS/FTD will be uncertain until these findings can be replicated. At this time, it is unclear whether these genes contribute to the penetrance of major disease genes, combine with environmental factors to trigger disease or represent quantitative traits in a polygenic disease model. These genes with small contributions will not be discussed here, as this review concentrates on the monogenic or oligogenic causes that can help develop effective therapies in the short term.

The clinical, genetic and pathological connections between ALS and FTD are discussed in detail in this review with the purpose of describing a new ALS/FTD spectrum that will allow clinicians to diagnose these conditions and help researchers develop therapeutic strategies that target one or both conditions.

\section{THE DEVASTATING ALS}

ALS is a relatively common neurodegenerative condition affecting as much as 1:350-500 adults. ${ }^{10}$ Although its overall prevalence is low (2 in 100000 ), the lifetime risk for ALS is higher due to its short disease course. The typical onset is in midlife to late-life and from diagnosis the disease progresses dramatically to cause paralysis and death within 2-3 years. Like for many other neurodegenerative conditions, there is no cure for ALS. This lack of therapies is based on a poor biological 
knowledge of the specific disease mechanisms and on the intrinsic complexity of ALS. The progressive paralysis in patients with ALS is a consequence of the dysfunction and loss of motor neurons located in the brainstem and spinal cord as well as in the motor cortex. ${ }^{11}$ Thus, this is a central brain condition, although the symptoms affect first the extremities due to the degeneration of the long axons of the central motor neurons. In its late stages, ALS affects the motor neurons controlling the respiratory muscles and the throat, causing breathing and swallowing difficulties that are usually the cause of death.

The progressive loss of motor neurons in ALS is typically accompanied by reactive astrocytes and microglia, and signs of neuroinflammation. Upper motor neurons show axonal degeneration and myelin loss. The surviving motor neurons contain cytoplasmic protein aggregates that are ubiquitinated. These protein aggregates contain mainly TDP-43, and also superoxide dismutase-1 (SOD1), FUS and other proteins. Based on this protein misfolding pathology, ALS belongs to the large class of proteinopathies that include $\mathrm{AD}$ and other highly prevalent conditions for which there are currently no disease-modifying therapies.

Classic ALS was described in the mid-1800s as a rapidly progressing motor neuron disease, but the phenotypes are actually quite variable as demonstrated by two famous patients. Lou Gehrig, for whom the disease is named, developed the classic ALS phenotype: he went from being a consistent and durable baseball hitter known as the 'iron horse' to full-blown motor neuron disease and death in 2 years. On the other hand, the cosmologist Stephen Hawkins started developing ALS symptoms in his early 20s but continues to produce brilliant work on cosmological theories at the age of 70 despite his advanced paralysis. Whereas Hawkins' cognitive abilities remain intact, other forms of ALS exhibit obvious cognitive loss. This is due to neuronal loss in the prefrontal and temporal cortex, neurons critical for maintaining executive functions. It is now recognised that up to $15 \%$ of patients with ALS also have a clear FTD diagnosis, with up to $50 \%$ showing some FTD symptoms. ${ }^{12}$ Although this overlap was recognised long ago, these patients were placed in a separate category from those exhibiting pure motor neuron disease. Genetics also contributes to the variability of ALS phenotypes: while most ALS mutations accelerate onset and disease course, SOD1-D90A leads to a slow disease progression. ${ }^{11} 13$ Some mutations are linked to specific symptoms, like cognitive impairment, while others are typically constraint to motor neuron disease. ${ }^{11}$ The complex clinical classification of ALS is relevant because disease subtypes reflect the underlying pathogenic mechanisms; hence, understanding the pathology will help develop the most effective treatments for each subtype.

\section{ALS, A SPORADIC DISEASE WITH GENETIC AND ENVIRONMENTAL CONTRIBUTIONS}

Like the highly prevalent AD and Parkinson's disease, ALS is mainly a sporadic disease with a 5\%-10\% autosomal dominant inheritance. However, the presence of co-occurring and de novo mutations in sporadic ALS raises the overall heritability for ALS, which was proposed to be as high as $60 \%$ in twin studies. ${ }^{11} 14$ Several genes with autosomal dominant effect are described here in some detail because these genes have been confirmed in multiple cohorts and animal studies have confirmed their contribution to disease (table 1 and figure 1). Genome-wide association studies have uncovered over 100 loci that predispose to disease with low penetrance, ${ }^{2} 9$ supporting the strong heritability of ALS. The contribution of environmental toxins and lifestyle to ALS has been widely reported, but no definitive factors are known to cause ALS. The high prevalence of ALS-related syndrome with dementia and parkinsonism in the Pacific island of Guam suggested a strong link to an environmental toxin, particularly seeds rich in cyanotoxins from the local diet. ${ }^{15}$ However, recent studies found that this condition has almost disappeared without sufficient evidence to prove the causative role of the diet. ${ }^{16}$ More recently, pesticides found in the blood of patients with ALS suggested their potential causative role of ALS clusters in Michigan. ${ }^{17}$ Age, occupation and lifestyle seem to influence the risk for ALS, but no specific toxin has so far been clearly identified as the direct cause of ALS.

\section{SOD1, THE FIRST GENETIC LINK TO ALS}

In 1993, mutations in the SOD1 gene were identified for the first time in an ALS family. ${ }^{18}$ Autosomal dominant SOD1 mutations affect around $13 \%$ of familial ALS and are also present in a small percentage $(1 \%)$ of sporadic ALS. At this time, $>170$ different mutations distributed throughout the 153 amino acids

Table 1 Major ALS/FTD genes

\begin{tabular}{|c|c|c|c|c|}
\hline ALS/FTD & Gene & Mutation & Protein/function & Disease contribution \\
\hline ALS & SOD1 & Missense & Superoxide dismutase $1 /$ oxidative stress & fALS $12 \%$, sALS 1\% \\
\hline ALS & OPN & & Optineurin/vesicle trafficking & fALS $<1 \%$, sALS $<1 \%$ \\
\hline ALS/FTD & C9orf72 & Non-coding GGGGCC expansion & C9orf72/GDP-GTP nucleotide exchange factor & $\begin{array}{l}\text { fALS } 40 \% \text {, sALS } 7 \% \\
\text { sFTD } 25 \% \text {, sFTD } 6 \%\end{array}$ \\
\hline ALS/FTD & TARDBP & Missense/nonsense & TDP-43/RNA-binding, processing & $\begin{array}{l}\text { fALS } 5 \% \text {, sALS }<1 \% \\
\text { fFTD } 1 \%\end{array}$ \\
\hline ALS/FTD & FUS & Missense/nonsense & FUS/RNA-binding, processing & fALS $4 \%$, sALS $<1 \%$ \\
\hline ALS/FTD & VCP & Missense & Valosin-containing protein/proteasome, vesicle trafficking & $\begin{array}{l}\text { fALS } 1 \% \\
\text { fFTD }<1 \%\end{array}$ \\
\hline ALS/FTD & UBQLN1 & Missense & Ubiquilin-1/protein degradation & $\mathrm{X}$ linked ALS/FTD $<1 \%$, sALS $2 \%$ \\
\hline ALS/FTD & SQSTM1 & Missense/deletion & p62/protein degradation & $\begin{array}{l}\text { fALS } \sim 1 \% \text {, sALS } 4 \% \\
\text { fFTD } 2 \%\end{array}$ \\
\hline ALS/FTD & CHMP2B & Missense & Charged multivesicular protein $2 \mathrm{~B} /$ vesicle trafficking & $\mathrm{fFTD}<1 \%$ \\
\hline FTD & MAPT & Missense and splice-site & Tau/microtubule binding and stabilisation & fFTD $\sim 10 \%$ \\
\hline FTD & GRN & Missense & Granulin/tissue repair & fFTD 20\%, sFTD 5\% \\
\hline
\end{tabular}

ALS, amyotrophic lateral sclerosis; FTD, frontotemporal dementia; FUS, fused in sarcoma; f, familial; GRN, granulin; MAPT, microtubule-associated protein tau; s, sporadic; $\mathrm{VCP}$, valosin-containing protein. 


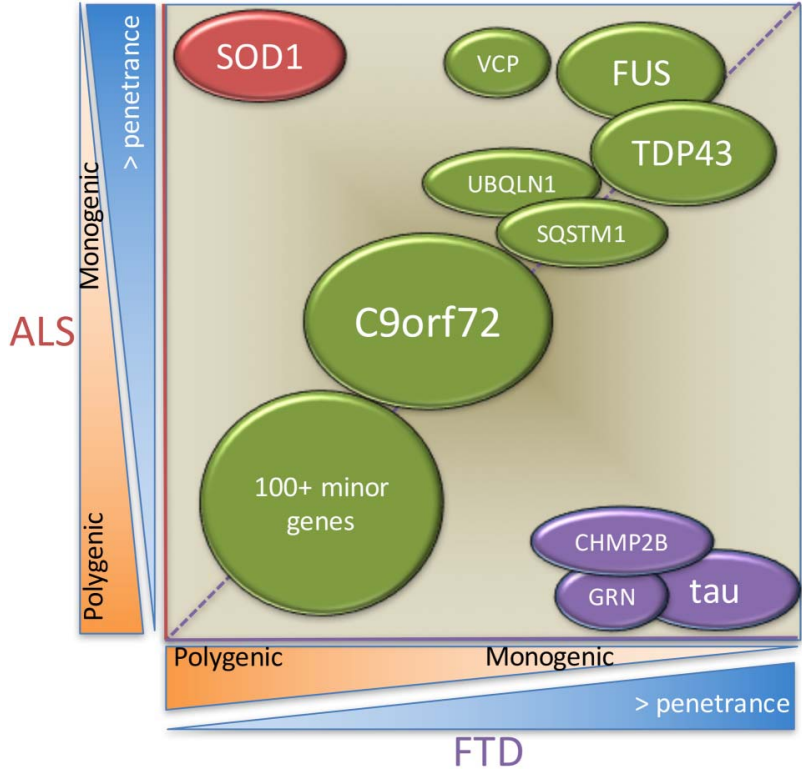

Figure 1 Genetic contribution to amyotrophic lateral sclerosis (ALS) and frontotemporal dementia (FTD). The ALS and FTD phenotypes are presented along $\mathrm{Y}$-axis and $\mathrm{X}$-axis, with a gradient from polygenic, low penetrance contributions to monogenic, high penetrance contributions along both axes. The relative contribution of the main ALS/FTD genes is represented by their size and the contribution to each phenotype by the proximity to each axis. The genes along the central diagonal have similar contributions to ALS and FTD phenotypes. Superoxide dismutase-1 (SOD1), tau and granulin (GRN) represent pure, monogenetic ALS and FTD. Chromosome 9 open reading frame 72 (C9orf72) may represent an oligogenic model of both ALS and FTD. SQSTM1, sequestrome-1; VCP, valosin-containing protein.

of SOD1 are known to cause autosomal dominant ALS. SOD1 mutations like A4V typically induce early onset or rapid progression, whereas the recessive D90A causes a slow disease course. These findings demonstrate the causative role of SOD1 mutations in ALS and suggest a yet unknown complexity in the SOD1-dependent mechanisms mediating pathogenesis. SOD1 normally forms dimers in the cytosol to convert superoxide radicals into oxygen and hydrogen peroxide, thus protecting cells from oxidative stress. Most mutations reduce the catalytic activity of SOD1, but mouse models do not support SOD1 loss of function (LOF) as the cause of ALS pathogenesis. ${ }^{19}$ Since SOD1 mutations promote misfolding and aggregation, ${ }^{20} 21$ gain-of-function (GOF) mechanisms similar to those implicated in other common protein misfolding disorders or proteinopathies are favoured by most investigators. Wild-type SOD1 is also found in aggregates in sporadic patients with ALS, suggesting that environmental or metabolic factors that promote SOD1 misfolding can trigger pathogenesis. Alternatively, motor neuron dysfunction can result in SOD1 aggregation as a secondary event. Several cellular pathways seem to be altered as a consequence of SOD1 aggregation, including blocked proteasomal degradation, blocked autophagy, mitochondria dysfunction and others (figure 2). ${ }^{22-24}$ More research is needed to find interventions that prevent SOD1 aggregation or mitigate the cellular responses downstream of pathogenic SOD1.

\section{FTD, THE SECOND MOST PREVALENT DEMENTIA}

FTD, also known as frontotemporal lobar dementia (FTLD), is the second most common form of dementia after $\mathrm{AD}$, with a prevalence of up to 4-22 in 10000 in those aged between 45 and 65 years, with the wide range mostly due to a high rate of misdiagnosis as $\mathrm{AD}{ }^{25}$ The dementia arises from the progressive degeneration of the frontal and anterior temporal lobes. As described above for ALS, typical FTD is a heterogeneous condition with behavioural and language variants, and a wide range of survival time after diagnosis (2-20 years). Although dementia is the key clinical phenotype of FTD, around $15 \%$ are also diagnosed with ALS and up to $40 \%$ of patients with FTD show motor neuron disease. ${ }^{26} 27$ Thus, 'pure' ALS and FTD are bookends of a disease spectrum with high phenotypic complexity.

FTD is another proteinopathy characterised by the accumulation of aggregated proteins in the cytoplasm of neurons and glia in the affected regions with no cure. The cellular pathology of FTD is quite complex, which resulted in a subclassification of the disease based on the proteins present in the inclusions. In contrasts to the highly homogeneous AD pathology, FTD can present with five different protein pathologies, with Tau and TDP-43 representing 90\% of all the cases. The rest contain FUS, ubiquitin or no protein pathology. This variation in protein pathology complicates the identification of common pathological triggers and cellular mechanisms in FTD. However, the common dementia phenotype suggests the existence of shared pathogenic mechanisms that can be unravelled through genetics and mechanistic studies.

\section{TAU, THE FIRST FTD GENE}

The first genetic association in FTD was known as FTLD-17 due to a strong region of interest in chromosome 17 . These patients exhibited autosomal dominant dementia, parkinsonism and behavioural changes. FTLD-17 was characterised by robust cytoplasmic aggregates positive for microtubule-associated protein tau, which maps on chromosome 17 , making tau the obvious genetic candidate. Subsequent cloning of the gene responsible for FTDP-17 identified several mutations in tau (figure 1). ${ }^{28-30}$ Currently, 44 different mutations in tau are associated with FTLD-17, either missense mutations or mutations that alter splicing of the microtubule domain repeats ( $3 R$ or $4 R$ ). The $3 R / 4 R$ ratio seems to be important for tau stability and mutations that promote $4 \mathrm{R}$ tau result in tau aggregation and cytoskeleton disorganisation (figure 2). ${ }^{31}$ Missense mutations may alter other functions of tau or increase its phosphorylation, again resulting in tau aggregation. Tau pathology is well known for its involvement in $\mathrm{AD}$ tangles, although tau mutations do not occur in $\mathrm{AD}$. It is interesting to note that the first gene identified in FTD causes a pure FTD phenotype without motor neuron disease similar to the role of SOD1 in ALS. Apparently, these pure ALS and FTD lineages were highly homogeneous, which facilitated the identification of the genes responsible for the pathologies.

When many patients with FTLD-17 turned out to have no mutations in tau or tau aggregates, subsequent sequencing of nearby genes led to the identification of mutations in the granulin $(G R N)$ gene. ${ }^{32} 33$ GRN encodes the secreted glycoprotein progranulin, which can be cleaved to form several granulins whose function is related to glucose sensing and tissue repair. GRN mutations are more common than tau mutations in FTLD (figure 1) and only one case has been reported to also show ALS, although it is not clear that GRN is responsible for the ALS phenotype.

\section{GENETIC DISCOVERIES AND THE BIRTH OF THE ALS/FTD DISEASE SPECTRUM}

Prior to the recent genetic discoveries, two main arguments linked ALS and FTD: shared clinical phenotypes and protein pathology. Studies over the last 30 years have confirmed the 


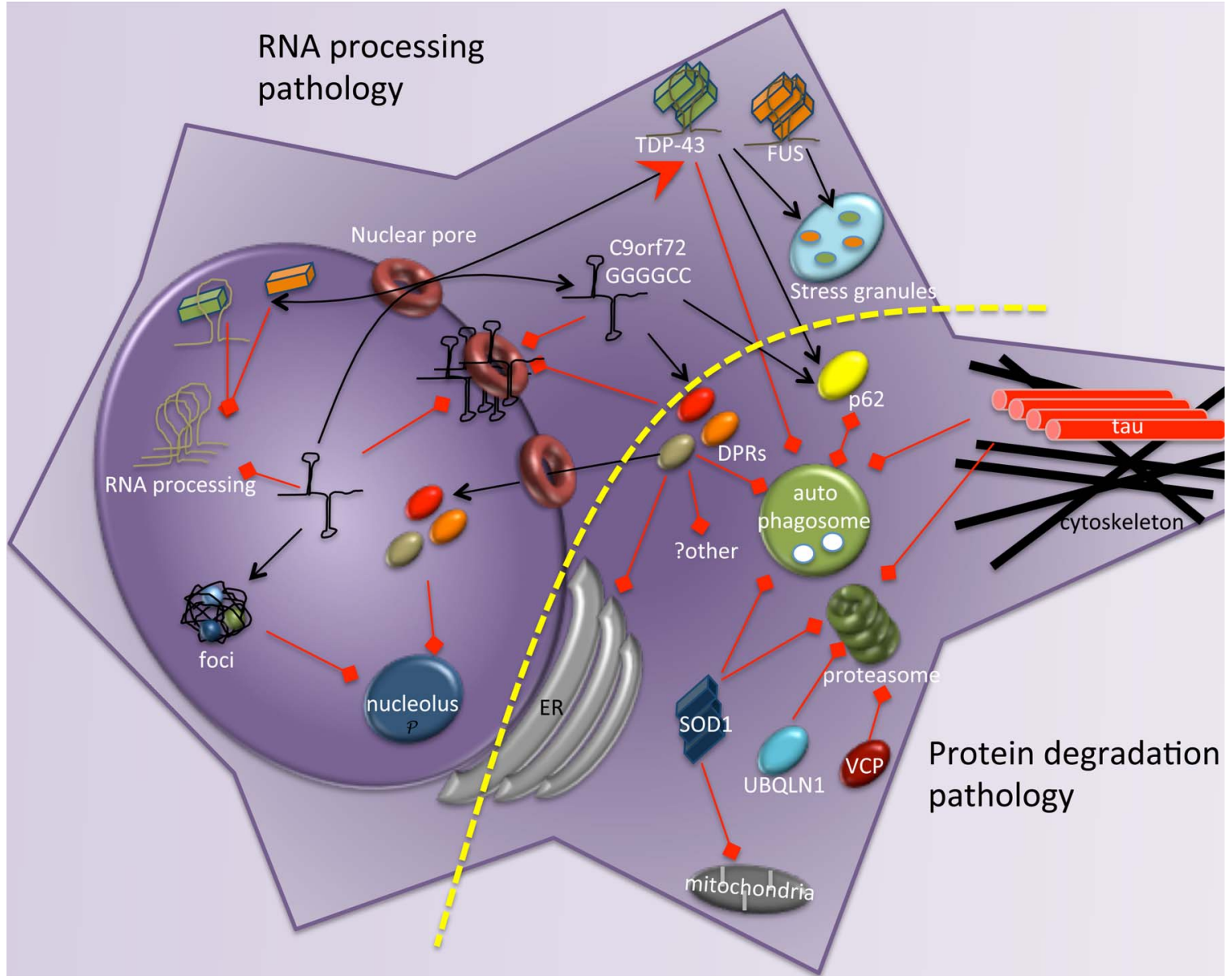

Figure 2 Cellular mechanisms of toxicity in amyotrophic lateral sclerosis (ALS)/frontotemporal dementia (FTD). Representation of a neuron and the perturbations caused by the main ALS/FTD genes. The nucleus contains foci with expanded chromosome 9 open reading frame 72 (C9orf72) mRNA that sequesters proteins critical for RNA processing. Nuclear depletion of TAR DNA-binding protein-43 (TDP-43) and fused in sarcoma (FUS) alters mRNA splicing and maturation. The nucleolus seems to be the target of dipeptide repeats (DPRs) and aberrant RNAs. Expanded C9orf72 mRNA and DPRs block nuclear pores, affecting large numbers of mRNAs to accumulate in the nucleus. Mutant TDP-43 and FUS accumulate preferentially in the cytosol and incorporate in stress granules. DPRs and mutant Superoxide dismutase-1 (SOD1), UBQLN1, valosin-containing protein (VCP) and p62 target and inhibit protein degradation machinery. Mutant tau accumulates in tangles and causes the disorganisation of the cytoskeleton. This is a simplification of all the mechanisms proposed for all the ALS/FTD genes. A dashed yellow line separates the RNA processing and protein degradation mechanisms, and the arrows crossing this line indicate the connections between the two major cellular processes.

co-occurrence of ALS and FTD, with around 15\% of ALS cases showing a clear diagnosis of FTD and another $15 \%$ of patients with FTD displaying ALS. ${ }^{12} 2734$ These numbers may underestimate the co-occurrence of ALS and FTD because of the dominance of one condition, but some estimates suggest that up to $50 \%$ of ALS show some signs of cognitive decline and vice versa. With regard to the cellular pathology, it is well known that ubiquitin and TDP-43 inclusions are highly prevalent in both ALS and FTD, suggesting common cellular perturbations and molecular mechanisms. ${ }^{35}$ These two important clues were sidelined until just a few years ago, when genetic evidence helped solidify the idea of an ALS/FTD disease continuum with pure ALS and FTD representing the extremes (bookends).

The identification of SOD1 and tau in the 1990s as genetic factors in ALS and FTD, respectively, supported the traditional view of two distinct clinical entities. However, SOD1 and tau explained as small percentage of the inherited risk for each disease and even less of the sporadic diseases. With the advent of modern genome sequencing technologies, several efforts have yielded $>100$ genes contributing to the genetic risks of ALS and FTD. ${ }^{2}$ Most of these genes are 'minor contribution genes' that still need to be validated in multiple cohorts and functional studies. These genes can predispose to ALS/FTD by combining with mutations in major genes or by promoting common TDP-43 or RNA splicing pathologies. ${ }^{2}$ But much work is still needed to understand their contribution to disease and their pathogenic mechanisms. The next section will review the most prominent genes linking ALS and FTD.

\section{C9ORF72 AND MECHANISMS OF TOXICITY}

In 2011, non-coding GGGGCC expansions in C9orf72 were identified as the most common mutations in inherited forms of ALS (40\%) and FTD (25\%), and in a significant number of sporadic ALS (5\%-20\%) and FTD (6\%) (figure 1). ${ }^{3}{ }^{4}$ C9orf72 mutations in patients with ALS+FTD have been validated in several independent studies. These patients show neuronal inclusion pathology positive for ubiquitin and p62, but negative for TDP-43, indicating that another protein had a prominent role in ALS/FTD. Normal individuals have up to 20 hexanucleotide repeats and anywhere from 30 to thousands are found in patients. However, C9orf72 mutations are not fully penetrant, which accounts for the large prevalence of C9orf72 mutations 
in 'sporadic' ALS/FTD. This incomplete penetrance suggests the contribution of other mutations and environmental factors in disease onset and progression in C9orf72 families. Interestingly, the hexarepeat region of C9orf72 is located in between two non-coding exons, suggesting several, non-exclusive mechanisms mediating C9orf72 pathogenesis. Below is a brief review of all the potential mechanisms that can explain C9orf72 toxicity.

\section{C9orf72 LOF}

Recent analysis suggests that C9orf72 encodes for a protein with Guanosine diphosphate and triphosphate (GDP-GTP) nucleotide exchange factor activity. ${ }^{36}{ }^{37}$ Both C9orf72 mRNA and the C9orf72 protein are highly expressed in the brain in mice and humans. ${ }^{38}$ Studies have reported lower levels of C9orf72 mRNA in patients carrying the expansions and reductions in the long C9orf72 isoform. ${ }^{39}$ However, the short isoform seems to accumulate at higher levels and relocalise to the plasma membrane, suggesting a potential mechanism of toxicity, although the significance of these findings is unclear. Mice lacking C9orf72 function show autoimmune phenotypes, ${ }^{40}$ but not degeneration of motor neurons and frontal cortex, suggesting a minor contribution of LOF to C9orf72-mediated ALS/FTD.

\section{C9orf72 mRNA GOF}

The non-coding GGGGCC repeats place the C9orf72 mutations in a class of neurological disorders caused by non-coding repeats that includes myotonic dystrophy (MD) 1 and 2, spinocerebellar ataxias types 8,10 and 12 and fragile-X tremor ataxia syndrome. In these conditions, mRNAs carrying the repeat expansion accumulate in nuclear foci that titrate RNA-binding proteins, and perturb the maturation and splicing of other mRNAs, thus receiving the common name of RNA mis-splicing diseases (figure 2). ${ }^{41} 42$ Several arguments support the toxicity of mRNA, including the finding that the repeat alone without the gene context is toxic in model systems. Also, repeat expansions promote the transcription of the antisense mRNA, which are also found in the foci. In MD1, CUG repeats bind and titrate specific splicing factors, which result in altered protein expression profiles with a role in pathogenesis. GGGGCC repeats show high affinity for heterogeneous nuclear ribonucleoproteins (hnRNP), particularly hnRNP H, which has the potential to alter splicing. ${ }^{43}$ Other proteins are likely to bind GGGGCC repeats with moderate to high affinity, potentially altering maturation of large numbers of transcripts.

\section{C9orf72 repeat associated non-ATG products GOF}

One of the most surprising findings emerging from the noncoding repeat expansions is the production of peptide repeats through unconventional repeat associated non-ATG (RAN) translation. RAN translation was first described in the trinucleotide repeat CUG produced in MD1 as a potential new mechanism mediating pathogenesis. ${ }^{44}$ Since RAN translation does not need ATG to establish the reading frame, both sense and antisense strands can produce five different polymonomeric proteins. The long GGGGCC repeats from C9orf72 also undergo RAN translation, but the hexarepeats produce dipeptide repeats (DPR) (figure 2): ${ }^{45-49}$ the sense hexarepeat produces GA, GR and GP DPRs and the antisense strand produces PG, PR and PA. These DPRs have been observed in brain tissue from patients, induced pluripotent stem (iPS) cells and animal models, although their distribution does not correlate with the regions damaged in ALS/FTD. ${ }^{50}$ This observation may not be highly relevant because small amounts of highly toxic DPRs may be enough to kill susceptible neurons. Directed expression of dipeptides containing arginine (ATG-PR and ATG-GR) demonstrated high toxicity in vivo, while ATG-PA and ATG-GA and hexarepeats with stop codons were not toxic. ${ }^{51-53}$ These results suggested that PR and GR are the main disease triggers, with a minor contribution for the mRNA foci.

So far, GOF mechanisms explain better the experimental data. But the relative contribution of mRNA foci or DPRs is not clear at this time (figure 2). Experiments have not clearly elucidated this issue because of the limitations of expressing pure RNA repeats without DPRs. The addition of stop codons to prevent RNA translation disturbs the formation of tertiary mRNA structures and reduces the ability to trap nuclear proteins, thus altering mRNA foci toxicity. The only apparent solution to these studies would require inhibiting RAN translation to express pure RNA repeats in the absence of DPRs. Ultimately, it is possible that a combination of RNA and DPR toxicity results in synergistic effects and, hence, the two cannot be completely dissociated form mutant C9orf72 toxicity.

\section{Cellular mechanisms of C9orf72 toxicity}

Two main cellular mechanisms seem to explain the toxicity of GGGGCC repeats. The first implicates the nucleus, a convergence point for RNA foci and DPRs, suggesting nuclear stress as a pathogenic mechanism (figure 2). The interaction of GGGGCC repeats with specific RNPs is expected to alter mRNA splicing and maturation. In fact, transcriptomic studies have confirmed altered expression profiles in patients, including extensive abnormal splicing involving thousands of substrates. ${ }^{43}$ GGGGCC repeats and some DPRs colocalise in the nucleolus, the site where rRNAs are processed and assembled. ${ }^{54}$ Nucleolar dysfunction has been reported in patients and several models (figure 2), ${ }^{54} 55$ although the specific mechanisms mediating this toxicity are unknown at this time.

Three recent publications linked the toxicity of mutant C9orf72 to perturbations in the nucleocytoplasmic transport of proteins and RNA (figure 2). A candidate screen for RNA-binding proteins found that overexpression of the nuclear pore protein RanGAP suppressed GGGGCC toxicity in Drosophila. ${ }^{56}$ A genome-wide deficiency screen in Drosophila found two genetic modifiers of GGGGCC implicated in the nucleocytoplasmic machinery, which led to the identification of additional genetic modifiers among components of the pore complex. ${ }^{57}$ Moreover, an overexpression screen in yeast found 62 modifiers of PR toxicity, including 11 components of the nucleocytoplasmic transport machinery. ${ }^{51}$ The screen also identified additional modifiers in diverse pathways, providing a more complete picture of the complex cellular mechanisms of PR toxicity. Interestingly, GGGGCC repeats induced cytoplasmic accumulation of TDP-43, revealing an insightful connection between the two pathologies.

\section{TDP-43 AND MECHANISM OF TOXICITY}

In 2006, most tau-negative FTD cases were found to accumulate cytoplasmic inclusions containing ubiquitinated, phosphorylated and truncated TDP-43. ${ }^{35}$ TDP-43 inclusions were also identified in large numbers of sporadic and familial ALS and are typically found in carriers of C9orf72 mutations. This observation was seminal to solidify the idea of an ALS/FTD continuum based on shared molecular pathology. The fact that TDP-43 is aggregated, ubiquitinated, phosphorylated and mislocalised in the cytosol in most cases of ALS and FTD provided important clues to the potential contribution of TDP-43 in neurodegeneration. After the characterisation of this pathological similarity between sporadic forms of FTD and ALS, mutations in TDP-43 were identified in 
familial forms of ALS (4\%) and FTD (1\%) (figure 1). ${ }^{58-60}$ TDP-43 is an RNA-binding protein encoded by TARDBP normally found in the nucleus and proposed to regulate transcription, splicing (including its own mRNA), ${ }^{61}$ miRNA biogenesis and mRNA transport. Most mutation in familial ALS and FTD are located in the C-terminal RNA-binding domain, which are expected to alter the interaction with mRNAs and affect their splicing.

\section{TDP-43 LOF mechanisms}

As is the case for several genes implicated in neurodegeneration, both LOF and GOF have been proposed to mediate TDP-43 pathogenesis. LOF of TDP-43 is supported by the mutations in the RNA binding domain and the mislocalisation of the protein from the nucleus to the cytoplasm, which also occurs in sporadic ALS and FTD. ${ }^{62}$ Depletion of TDP-43 in the nucleus alters splicing and cytosolic TDP-43 can bring along mRNA molecules that prevent their processing and maturation, thus causing a LOF of these downstream molecules (figure 2). Several animal models indicate that TDP-43 is required for viability in embryonic and postembryonic stages, but this does not inform us about the contribution of TDP-43 LOF to neurodegeneration. Although the initial triggers promoting TDP-43 accumulation in the cytosol are unknown, pathological forms of TDP-43 induce mislocalisation of normal TDP-43, further causing a depletion of TDP-43 in the nucleus.

\section{TDP-43 GOF mechanisms}

Both overexpression and underexpression of TDP-43 are toxic in animal models, suggesting that tight regulation of TDP-43 expression is critical to prevent pathology. In this regard, the autoregulation of TDP-43 through binding its own mRNA suggests potential feedback mechanisms for TDP-43 accumulation and mislocalisation. ${ }^{62}$ TDP-43 binds valosin-containing protein (VCP) and has the potential to alter VCP distribution and function, thus connecting TDP-43 to the protein degradation machinery. TDP-43 belongs to a large class of amyloid proteins that form aggregates containing misfolded conformations. These aggregates can recruit other proteins, and thus deplete them and interfere with their normal function (figure 2). Additionally, small soluble assemblies of TDP-43 have the potential to be transmitted to neighbouring cells by active and passive mechanisms, although experimental support for this is still missing. Recent data suggest that accumulation of several amyloids in the cytoplasm, including TDP-43, impair nucleocytoplasmic transport, revealing a mechanistic connection between TDP-43 and C9orf72. ${ }^{63}$

\section{FUS AND MECHANISM OF TOXICITY}

FUS was identified as a component of neuronal inclusions that were SOD1 and TDP-43 negative and ubiquitin positive in patients with ALS, leading to the identification of mutations in FUS in familial ALS (figure 1). ${ }^{64}{ }^{65}$ Like TDP-43, FUS is a nuclear protein that shuttles to and from the cytoplasm, has an RNA-binding domain in the C-terminus, and is thought to be implicated in transcription, splicing and mRNA transport. ${ }^{66}$ FUS mutations account for $4 \%$ of familial ALS, 1\% of sporadic ALS and a small percentage of familial FTD. However, FUS pathology is observed in sporadic FTD and in patients with ALS/FTD. The mutations disrupt binding to transportin, which shuttles FUS and other proteins to the nucleus, thus resulting in the cytosolic accumulation of FUS (figure 2) ${ }^{67}$ FUS binds thousands of mRNA substrates and FUS LOF alters the splicing of $>1000$ genes, some of which are neuronal genes that could participate in pathogenesis. As is the case with TDP-43, both LOF and GOF mechanisms have been proposed in FUS pathogenesis, although no specific pathways are known at this time. Despite the similarities with TDP-43, FUS does not colocalise with TDP-43 in cytoplasmic inclusions and their mRNA targets are quite different, suggesting that they are not part of a linear pathway. Given the many targets of FUS and TDP-43, they may induce degeneration by altering the processing and transport of large numbers of mRNAs.

\section{VCP, SQSTM1, UBQLN2 AND CHARGED MULTIVESICULAR PROTEIN 2B}

In addition to the main ALS/TDP genes described above, a small number of genes also play a significant role in inherited forms of ALS/FTD. VCP is a highly abundant class II AAA (ATP-associated with diverse cellular activities) protein that targets a variety of substrates for degradation by the ubiquitin-proteasome pathway. VCP mutations cause a complex syndrome with myopathy, FTD and $1 \%$ of familial ALS (figure 1). ${ }^{68} 69$ Due to the normal function of VCP in protein degradation, VCP mutations cause deficient proteolysis and accumulation of ubiquitinated substrates (figure 2). On this same line, mutations in UBQLN2, which encodes the regulator of protein degradation ubiquilin-2, were identified in ALS with FTLD (figure 1). ${ }^{70}$ These patients showed accumulation of UBQLN2 in inclusions positive for ubiquitin, p62 and FUS. This UBQLN2 pathology is also present in sporadic ALS/FTD cases and in mutant C9orf72 carriers (figure 2). SQSTM1 or p62 is an inducible protein encoded by the SQSTM1 gene implicated in cell survival and death. P62 has an ubiquitin-associated domain that marks substrates for degradation. p62 inhibits autophagy through target of rapamycin and is degraded by binding to LC3 and incorporation into the autophagosome. Due to its role in cellular stress, candidate studies revealed mutations in p62 in familial ALS and FTD (figure 1). ${ }^{71}{ }^{72}$ Additionally, p62 has been found in cytoplasmic aggregates in patients carrying C9orf72 mutations co-aggregated with TDP-43 or ubiquitin. ${ }^{73}$ Deficient proteolysis has been suggested as a secondary mechanism of toxicity in several proteinopathies that accumulate ubiquitinated substrates in the nucleus or the cytoplasm, and it seems to be a critical player in ALS/FTD as well.

Lastly, mutations in charged multivesicular protein 2B (CHMP2B) were found to be responsible for TDP in chromosome 3 in European families. These patients develop parkinsonism and dystonia, but not motor neuron disease, and show cytosolic protein aggregation positive for ubiquitin and $\mathrm{p} 62$, but not TDP-43. Many additional genes with minor roles in ALS and/or FTD have been described in several recent reviews and will not be discussed here. ${ }^{2} 19$

\section{OLIGOGENIC MODEL OF ALS/FTD}

The traditional view for autosomal dominant conditions such as familial ALS and FTD is that mutations in one high penetrance gene were sufficient to cause disease. Although that is the case in patients carrying mutant SOD1 and tau, recent findings challenge drastically this monogenetic model. Despite the high prevalence of C9orf72 mutations in ALS/FTD, they have low penetrance and can be found with other mutations and in sporadic ALS/FTD. These observations suggest that low penetrance risk genes contribute to disease in combination with other minor genes or modulate disease onset and progression in combination with major genes (figure 1). ${ }^{74}$ This has been proven in a few cases in which second mutations have been identified in carriers of C9orf72 expansions and ataxin-2 polyglutamine expansions, TDP-43, FUS, SOD1, tau, SQSTM1, CHMP2B, 
UBQLN2 and several minor genes (reviewed in ref. 2). The combination of C9orf72 with ATXN2 seems to alter disease onset and progression. Interestingly, C9orf72 with TDP-43, FUS or SOD1 mutations causes pure ALS, whereas in combination with tau and SQSTM1 causes pure FTD (reviewed in ref. 2). Thus, C9orf72 increases the risk of developing ALS/FTD and the second mutation determines the pathology. Combinations of TDP-43, FUS and SOD1 with minor genes have been described due to the high incidence of double mutants in sporadic ALS. Although these observations are very revealing, the molecular and cellular mechanisms mediating the consequences of these combinations need to be elucidated experimentally. The polygenic or oligogenic models ${ }^{2}{ }^{75}$ explain two important aspects of ALS/FTD: the low penetrance of C9orf72 mutations and the wide clinical spectrum, where the extremes are likely mediated by combinations of common genes like C9orf72 with ALS-exclusive or FTD-exclusive second hits like SOD1 and tau.

\section{CONVERGENCE OF PATHOGENIC MECHANISMS: ABERRANT RNA PROCESSING AND PROTEIN DEGRADATION}

The review of the major ALS/FTD genes suggests that they mainly perturb two cellular processes: aberrant RNA processing and protein degradation (figure 2). Aberrant RNA processing includes titration of RNA binding proteins in foci, loss of nuclear TDP-43 and FUS affecting RNA maturation, splicing and transport, nuclear pore dysfunction preventing the export and translation of mRNAs, nucleolus dysfunction and formation of stress granules in the cytosol. Protein degradation is affected by several genes with functions closely associated with autophagy or proteasome-dependent degradation (p62, UBQLN1, VCP) and pathogenic proteins showing the ability to disrupt protein degradation: TDP-43, FUS. Tau, SOD1 aggregates and DPRs containing arginine. Interestingly, the main ALS/FTD mutations (C9orf72, TDP-43 and FUS) are involved in both cellular processes, connecting the pathogenic mechanisms and supporting a central role in the common pathogenesis. But additional connections have been uncovered between the two cellular pathways, suggesting that altering one leads to alterations in the other. For instance, aberrant protein degradation may lead to aberrant RNA processing through TDP-43 aggregation in the cytoplasm. This is supported by observations that mutations in VCP and UBQLN1 leads to mislocalisation of TDP-43, thus connecting both pathologies. All the different proteins capable of perturbing protein degradation (figure 2) can also alter RNA processing by promoting TDP-43/FUS aggregation and accumulation in stress granules, which sequester mRNA and RNA-binding proteins. Conversely, altered RNA processing can disrupt protein degradation through the loss of key factors, and the secondary TDP-43 depletion in aggregates can inhibit autophagy, linking TDP-43 to VCP, UBQLN2 and p62. Overall, there seems to be robust genetic and pathologic evidence connecting aberrant RNA processing and protein degradation to support a series of complex cellular mechanisms that can explain most ALS/TDP cases.

\section{THERAPEUTIC OPPORTUNITIES}

Understanding the disease mechanisms is key to design rationale therapies that specifically target the disease triggers and the symptoms. The first objective should be reducing the levels of the mutant gene products (mRNA and/or proteins) in patients carrying mutations in major genes. This alone should reduce the pathogenic trigger enough to allow the neurons to recover their normal function. Some of the therapies in this area include antibodies designed against mutant alleles that have already being tested for SOD $1^{76}$ and could be used also against mutant tau, TDP-43 and FUS. Therapeutic agents could also target the specific mRNA sequence of mutant ALS/FTD genes through antisense oligonucleotides. These agents are under investigation in spinal muscular atrophy patients AND individuals carrying non-coding repeats responsible for myotonic dystrophy $1 .{ }^{77} 78$ Based on the potential implication of the wild-type alleles for SOD1 and TDP-43 in pathogenesis of ALS/FTD, these therapies could have a more general application to most patients, not only those carrying mutations. Although these targeted interventions are ideal for eliminating known genetic causes of disease, these methods are still in experimental phase and need to address several important challenges, including long-term safety and brain penetration for central brain disorders like ALS and FTD. Some of these challenges can be solved with the use of viral and cell-based vectors that can be injected once in the brain and selfperpetuate while expressing therapeutic agents like single-chain antibodies or antisense oligonucleotides. Although these technologies have demonstrated their viability in laboratory animals, safety concerns still need to be addressed.

A complementary strategy would focus on the downstream pathways perturbed in patients with ALS/FTD. We have reviewed here several cellular processes directly perturbed by the major ALS/FTD genes. Although they seem to cover diverse processes, the convergence of all the genes into related cellular perturbations provides hope for finding traditional pharmacological agents (stable, soluble small molecules) that correct the damage caused by altered RNA processing and protein degradation. It seems logical to pursue strategies that activate autophagy and proteasomal degradation to solve the problem of accumulating amyloids, but these strategies seem to work only under very controlled conditions. Although counterintuitive, several strategies are available to determine the benefits of inhibiting the early stages of autophagy to prevent the accumulation of late vesicles fused to lysosomes that can leach their acidic content to the cytosol. Similarly, the accumulation of foci, the dysfunction of nucleoli and blockage of nuclear pores suggest that reducing the overall levels of transcription (not just of the mutant genes) could reduce the stress caused by aberrant RNA processing. Also, compounds that inhibit nuclear export (KPT-276) have shown benefits in Drosophila models of C9orf72, supporting the important role of this pathogenic mechanism. This strategy needs to be investigated carefully to determine its benefits without causing deleterious effects. A number of experimental strategies include small molecules designed to bind RNA hairpins and the TMPyP4 porphyrin that disrupts expanded C9orf72 mRNA binding to RNA-binding proteins. ${ }^{79} 80$ Ultimately, several of these approaches may need to be combined to maximise their effect on relevant pathways.

Current technological developments in iPS cells and CRISPR DNA editing hold the promise of restoring function to central nervous system neurons and glia, and curing patient carrying ALS/FTD mutations, respectively. These technologies are clearly not ready for general use, but limited studies in peripheral tissues support their utility. ${ }^{81}$ Given the technical, regulatory and safety hurdles for these 'blue skies' therapies, small molecules targeting the downstream pathways shared by a majority of patients will have a more immediate application.

\section{CONCLUSIONS}

Advances in genome sequencing have brought radical changes into our understanding of ALS/FTD from two separate clinical entities to a complex disease spectrum. At a pathological level, 
the SOD1 and tau pathologies fit perfectly in distinct motor neuron and cognitive disorders, but the shared TDP-43 pathology was puzzling. The discovery of C9orf72 hexarepeat expansions in familial forms of ALS and FTD forced the revision of previous clinical and pathological reports for a connection between these two diseases. The common TDP-43 pathology makes more sense in the context of overlapping clinical phenotypes. Together with the genetics of C9orf72, all data available contribute to describe a complex neurodegenerative condition with extremes representing pure ALS and FTD, and the rest represented by different degrees of combined phenotypes.

Despite the clarity provided by the recognition of an ALS/ FTD spectrum, the complex genetics and pathology of these conditions still need further clarification. Over a hundred genes contribute to the risk of ALS/FTD, but only a few are major genes with high penetrance. Most genes have minor contributions to the disease, supporting an oligogenic model where contributions from two or more genes trigger the disease. This is supported by many reports of individuals carrying two mutations, where the low penetrant C9orf72 mutations have been found together with mutations in several other ALS/FTD genes. In these cases, the second hit can explain how the extreme pure phenotypes arise. It is also clear that environmental factors contribute to ALS, suggesting that low penetrance mutations together with external triggers can result in motor neuron disease.

Much work is still needed to understand the complexity of ALS/FTD, including the contribution of most minor genes and the molecular mechanisms of ALS/FTD pathologies. But the field has already taken giant steps towards integrating the pathologies, leading to new hypotheses that should launch research to a higher level of mechanistic understanding. Only when the molecular targets are clearly identified will be possible to develop therapeutic strategies with disease-modifying potential, including therapies against several targets combined with improved symptomatic therapies.

Acknowledgements The authors are thankful for the secretarial assistance and for all the suggestions for improving the manuscript from friends and collaborators.

Contributors W-JH conceived this review; A-LJ, XZ, W-WC and W-JH contributed to drafting the article, revising it critically for important intellectual content and approved the final version submitted to the journal. W-JH as the senior author is responsible for the final content and guarantor.

Competing interests None declared.

Provenance and peer review Commissioned; externally peer reviewed.

\section{REFERENCES}

1 Ng AS, Rademakers R, Miller BL. Frontotemporal dementia: a bridge between dementia and neuromuscular disease. Ann N Y Acad Sci 2015;1338:71-93.

2 Lattante $S$, Ciura S, Rouleau GA, Kabashi E. Defining the genetic connection linking amyotrophic lateral sclerosis (ALS) with frontotemporal dementia (FTD). Trends Genet 2015:31:263-73.

3 DeJesus-Hernandez M, Mackenzie IR, Boeve BF, Boxer AL, Baker M, Rutherford NJ, Nicholson AM, Finch NA, Flynn H, Adamson J, Kouri N, Wojtas A, Sengdy P, Hsiung GY, Karydas A, Seeley WW, Josephs KA, Coppola G, Geschwind DH, Wszolek ZK, Feldman H, Knopman DS, Petersen RC, Miller BL, Dickson DW, Boylan $\mathrm{KB}$, Graff-Radford NR, Rademakers R. Expanded GGGGCC hexanucleotide repeat in noncoding region of C9ORF72 causes chromosome 9p-linked FTD and ALS. Neuron 2011;72:245-56

4 Renton AE, Majounie E, Waite A, Simón-Sánchez J, Rollinson S, Gibbs JR, Schymick JC, Laaksovirta H, van Swieten JC, Myllykangas L, Kalimo H, Paetau A, Abramzon Y, Remes AM, Kaganovich A, Scholz SW, Duckworth J, Ding J, Harmer DW, Hernandez DG, Johnson JO, Mok K, Ryten M, Trabzuni D, Guerreiro RJ, Orrell RW, Neal J, Murray A, Pearson J, Jansen IE, Sondervan D, Seelaar $H$, Blake D, Young $K_{\text {, }}$ Halliwell N, Callister JB, Toulson G, Richardson A, Gerhard A, Snowden J, Mann D, Neary D, Nalls MA, Peuralinna T, Jansson L, Isoviita VM, Kaivorinne AL, Hölttä-Vuori M, Ikonen E, Sulkava R, Benatar M, Wuu J, Chiò A, Restagno G,
Borghero G, Sabatelli M; ITALSGEN Consortium, Heckerman D, Rogaeva E, Zinman L, Rothstein JD, Sendtner M, Drepper C, Eichler EE, Alkan C, Abdullaev Z, Pack SD, Dutra A, Pak E, Hardy J, Singleton A, Williams NM, Heutink P, Pickering-Brown S, Morris HR, Tienari PJ, Traynor BJ. A hexanucleotide repeat expansion in C9ORF72 is the cause of chromosome 9p21-linked ALS-FTD. Neuron 2011;72:257-68.

5 van der Zee J, Gijselinck I, Dillen L, Van Langenhove T, Theuns J, Engelborghs S, Philtjens S, Vandenbulcke M, Sleegers K, Sieben A, Bäumer V, Maes G, Corsmit E, Borroni B, Padovani A, Archetti S, Perneczky R, Diehl-Schmid J, de Mendonça A, Miltenberger-Miltenyi G, Pereira S, Pimentel J, Nacmias B, Bagnoli S, Sorbi S, Graff C, Chiang HH, Westerlund M, Sanchez-Valle R, Llado A, Gelpi E, Santana I, Almeida MR, Santiago B, Frisoni G, Zanetti O, Bonvicini C, Synofzik M, Maetzler W, Vom Hagen JM, Schöls L, Heneka MT, Jessen F, Matej R, Parobkova E, Kovacs GG, Ströbel T, Sarafov $S$, Tournev I, Jordanova A, Danek A, Arzberger T, Fabrizi GM, Testi S, Salmon E, Santens P, Martin JJ, Cras P, Vandenberghe R, De Deyn PP, Cruts M, Van Broeckhoven C, van der Zee J, Gijselinck I, Dillen L, Van Langenhove T, Theuns J, Philtjens S, Sleegers K, Bäumer V, Maes G, Corsmit E, Cruts M, Van Broeckhoven C, van der Zee J, Gijselinck I, Dillen L, Van Langenhove T, Philtjens S, Theuns J, Sleegers K, Bäumer V, Maes G, Cruts M, Van Broeckhoven C,

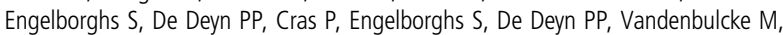
Vandenbulcke M, Borroni B, Padovani A, Archetti S, Perneczky R, Diehl-Schmid J, Synofzik M, Maetzler W, Müller Vom Hagen J, Schöls L, Synofzik M, Maetzler W, Müller Vom Hagen J, Schöls L, Heneka MT, Jessen F, Ramirez A, Kurzwelly D, Sachtleben C, Mairer W, de Mendonça A, Miltenberger-Miltenyi G, Pereira S, Firmo C, Pimentel J, Sanchez-Valle R, Llado A, Antonell A, Molinuevo J, Gelpi E, Graff C, Chiang $H H$, Westerlund $M$, Graff $C$, Kinhult Ståhlbom A, Thonberg $H$, Nennesmo I, Börjesson-Hanson A, Nacmias B, Bagnoli S, Sorbi S, Bessi V, Piaceri I, Santana I, Santiago B, Santana I, Helena Ribeiro M, Rosário Almeida M, Oliveira C, Massano J, Garret C, Pires P, Frisoni G, Zanetti O, Bonvicini C, Sarafov S, Tournev I, Jordanova A, Tournev I, Kovacs GG, Ströbel T, Heneka MT, Jessen F, Ramirez A, Kurzwelly D, Sachtleben C, Mairer W, Jessen F, Matej R, Parobkova E, Danel A, Arzberger T, Maria Fabrizi G, Testi S, Ferrari S, Cavallaro T, Salmon E, Santens P, Cras $P$, European Early-Onset Dementia Consortium. A pan-European study of the C9orf72 repeat associated with FTLD: geographic prevalence, genomic instability, and intermediate repeats. Hum Mutat 2013;34:363-73.

6 Majounie E, Renton AE, Mok K, Dopper EG, Waite A, Rollinson S, Chiò A, Restagno G, Nicolaou N, Simon-Sanchez J, van Swieten JC, Abramzon Y, Johnson JO, Sendtner M, Pamphlett R, Orrell RW, Mead S, Sidle KC, Houlden H, Rohrer JD, Morrison KE, Pall H, Talbot K, Ansorge O; Chromosome 9-ALS/FTD Consortium; French research network on FTLD/FTLD/ALS; ITALSGEN Consortium, Hernandez DG, Arepalli S, Sabatelli M, Mora G, Corbo M, Giannini F, Calvo A, Englund E, Borghero G, Floris GL, Remes AM, Laaksovirta H, McCluskey L, Trojanowski JQ, Van Deerlin VM, Schellenberg GD, Nalls MA, Drory VE, Lu CS, Yeh TH, Ishiura H, Takahashi Y, Tsuji S, Le Ber I, Brice A, Drepper C, Williams N, Kirby J, Shaw P, Hardy J, Tienari PJ, Heutink P, Morris HR, Pickering-Brown S, Traynor BJ. Frequency of the C9orf72 hexanucleotide repeat expansion in patients with amyotrophic lateral sclerosis and frontotemporal dementia: a cross-sectional study. Lancet Neurol 2012;11:323-30.

7 Andersen PM, Al-Chalabi A. Clinical genetics of amyotrophic lateral sclerosis: what do we really know? Nat Rev Neurol 2011;7:603-15.

8 Van Langenhove T, van der Zee J, Van Broeckhoven C. The molecular basis of the frontotemporal lobar degeneration-amyotrophic lateral sclerosis spectrum. Ann Med 2012;44:817-28.

9 Cirulli ET, Lasseigne BN, Petrovski S, Sapp PC, Dion PA, Leblond CS, Couthouis J, Lu YF, Wang Q, Krueger BJ, Ren Z, Keebler J, Han Y, Levy SE, Boone BE, Wimbish JR, Waite LL, Jones AL, Carulli JP, Day-Williams AG, Staropoli JF, Xin WW, Chesi A, Raphael AR, McKenna-Yasek D, Cady J, Vianney de Jong JM, Kenna KP, Smith BN, Topp S, Miller J, Gkazi A; FALS Sequencing Consortium, Al-Chalabi A, van den Berg LH, Veldink J, Silani V, Ticozzi N, Shaw CE, Baloh RH, Appel S, Simpson E, Lagier-Tourenne C, Pulst SM, Gibson S, Trojanowski JQ, Elman L, McCluskey L, Grossman M, Shneider NA, Chung WK, Ravits JM, Glass JD, Sims KB, Van Deerlin VM, Maniatis T, Hayes SD, Ordureau A, Swarup S, Landers J, Baas F, Allen AS, Bedlack RS, Harper JW, Gitler AD, Rouleau GA, Brown R, Harms MB, Cooper GM, Harris T, Myers RM, Goldstein DB. Exome sequencing in amyotrophic lateral sclerosis identifies risk genes and pathways. Science 2015;347:1436-41.

10 Johnston CA, Stanton BR, Turner MR, Gray R, Blunt AH, Butt D, Ampong MA, Shaw CE, Leigh PN, Al-Chalabi A. Amyotrophic lateral sclerosis in an urban setting: a population based study of inner city London. J Neurol 2006;253:1642-3.

11 Al-Chalabi A, Hardiman O. The epidemiology of ALS: a conspiracy of genes, environment and time. Nat Rev Neurol 2013;9:617-28.

12 Ringholz GM, Appel SH, Bradshaw M, Cooke NA, Mosnik DM, Schulz PE. Prevalence and patterns of cognitive impairment in sporadic ALS. Neurology 2005;65:586-90

13 Luigetti M, Conte A, Madia F, Marangi G, Zollino M, Mancuso I, Dileone M, Del Grande A, Di Lazzaro V, Tonali PA, Sabatelli M. Heterozygous SOD1 D90A mutation presenting as slowly progressive predominant upper motor neuron amyotrophic lateral sclerosis. Neurol Sci 2009;30:517-20.

14 Al-Chalabi A, Fang F, Hanby MF, Leigh PN, Shaw CE, Ye W, Rijsdijk F. An estimate of amyotrophic lateral sclerosis heritability using twin data. I Neurol Neurosurg Psychiatry 2010;81:1324-6. 
15 Koerner DR. Amyotrophic lateral sclerosis on Guam. Ann Intern Med 1952;37:1204-20.

16 Bradley WG, Banack SA, Cox PA. The ALS/PDC syndrome of Guam and the cycad hypothesis. Neurology 2009;72:473-4, 476; author reply 75-6.

17 Su FC, Goutman SA, Chernyak S, Mukherjee B, Callaghan BC, Batterman S, Feldman EL. Association of environmental toxins with amyotrophic lateral sclerosis. JAMA Neurol 2016;73:803-11.

18 Rosen DR. Mutations in Cu/Zn superoxide dismutase gene are associated with familial amyotrophic lateral sclerosis. Nature 1993:364:362.

19 Bennion Callister J, Pickering-Brown SM. Pathogenesis/genetics of frontotemporal dementia and how it relates to ALS. Exp Neurol 2014;262(Pt B):84-90.

20 Basso M, Massignan T, Samengo G, Cheroni C, De Biasi S, Salmona M, Bendotti C, Bonetto V. Insoluble mutant SOD1 is partly oligoubiquitinated in amyotrophic latera sclerosis mice. J Biol Chem 2006;281:33325-35.

21 Bruijn LI, Houseweart MK, Kato S, Anderson KL, Anderson SD, Ohama E, Reaume AG, Scott RW, Cleveland DW. Aggregation and motor neuron toxicity of an ALS-linked SOD1 mutant independent from wild-type SOD1. Science 1998:281:1851-4

22 Chen S, Zhang X, Song L, Le W. Autophagy dysregulation in amyotrophic lateral sclerosis. Brain Pathol 2012;22:110-16.

23 Bendotti C, Marino M, Cheroni C, Fontana E, Crippa V, Poletti A, De Biasi S Dysfunction of constitutive and inducible ubiquitin-proteasome system in amyotrophic lateral sclerosis: implication for protein aggregation and immune response. Prog Neurobiol 2012;97:101-26.

24 Robberecht W, Philips T. The changing scene of amyotrophic lateral sclerosis. Nat Rev Neurosci 2013;14:248-64.

25 Sieben A, Van Langenhove T, Engelborghs S, Martin JJ, Boon P, Cras P, De Deyn PP, Santens P, Van Broeckhoven C, Cruts M. The genetics and neuropathology of frontotemporal lobar degeneration. Acta Neuropathol 2012;124: 353-72.

26 Lomen-Hoerth C, Murphy J, Langmore S, Kramer JH, Olney RK, Miller B. Are amyotrophic lateral sclerosis patients cognitively normal? Neurology 2003;60:1094-7.

27 Burrell JR, Kiernan MC, Vucic S, Hodges JR. Motor neuron dysfunction in frontotemporal dementia. Brain 2011;134(Pt 9):2582-94.

28 Clark LN, Poorkaj P, Wszolek Z, Geschwind DH, Nasreddine ZS, Miller B, Li D, Payami H, Awert F, Markopoulou K, Andreadis A, D'Souza I, Lee VM, Reed L, Trojanowski JQ, Zhukareva V, Bird T, Schellenberg G, Wilhelmsen KC. Pathogenic implications of mutations in the tau gene in pallido-ponto-nigral degeneration and related neurodegenerative disorders linked to chromosome 17. Proc Natl Acad SCi USA 1998:95:13103-7.

29 Hutton $M$, Lendon $C L$, Rizzu P, Baker M, Froelich $S$, Houlden $H$, Pickering-Brown $S$ Chakraverty S, Isaacs A, Grover A, Hackett J, Adamson J, Lincoln S, Dickson D, Davies P, Petersen RC, Stevens M, de Graaff E, Wauters E, van Baren J, Hillebrand M, Joosse M, Kwon JM, Nowotny P, Che LK, Norton J, Morris JC, Reed LA, Trojanowski J, Basun H, Lannfelt L, Neystat M, Fahn S, Dark F, Tannenberg T, Dodd PR, Hayward N, Kwok JB, Schofield PR, Andreadis A, Snowden J, Craufurd D, Neary D, Owen F, Oostra BA, Hardy J, Goate A, van Swieten J, Mann D, Lynch T, Heutink $P$. Association of missense and $5^{\prime}$-splice-site mutations in tau with the inherited dementia FTDP-17. Nature 1998;393:702-5.

30 Spillantini MG, Murrell JR, Goedert M, Farlow M, Klug A, Ghetti B. Mutation in the tau gene in familial multiple system tauopathy with presenile dementia. Proc Natl Acad Sci USA 1998;95:7737-41.

31 Hutton M. Missense and splice site mutations in tau associated with FTDP-17: multiple pathogenic mechanisms. Neurology 2001;56(Suppl 4):S21-5.

32 Baker M, Mackenzie IR, Pickering-Brown SM, Gass J, Rademakers R, Lindholm C, Snowden J, Adamson J, Sadovnick AD, Rollinson S, Cannon A, Dwosh E, Neary D, Melquist S, Richardson A, Dickson D, Berger Z, Eriksen J, Robinson T, Zehr C, Dickey CA, Crook R, McGowan E, Mann D, Boeve B, Feldman H, Hutton M. Mutations in progranulin cause tau-negative frontotemporal dementia linked to chromosome 17. Nature 2006:442:916-19.

33 Cruts M, Gijselinck I, van der Zee J, Engelborghs S, Wils $H$, Pirici D, Rademakers $R$ Vandenberghe R, Dermaut B, Martin JJ, van Duijn C, Peeters K, Sciot R, Santens P, De Pooter T, Mattheijssens M, Van den Broeck M, Cuijt I, Vennekens K, De Deyn PP, Kumar-Singh S, Van Broeckhoven C. Null mutations in progranulin cause ubiquitin-positive frontotemporal dementia linked to chromosome 17q21. Nature 2006:442:920-4

34 Lomen-Hoerth C, Anderson T, Miller B. The overlap of amyotrophic lateral sclerosis and frontotemporal dementia. Neurology 2002;59:1077-9.

35 Neumann M, Sampathu DM, Kwong LK, Truax AC, Micsenyi MC, Chou TT, Bruce J, Schuck T, Grossman M, Clark CM, McCluskey LF, Miller BL, Masliah E, Mackenzie IR, Feldman H, Feiden W, Kretzschmar HA, Trojanowski JQ, Lee VM. Ubiquitinated TDP-43 in frontotemporal lobar degeneration and amyotrophic lateral sclerosis. Science 2006:314:130-3.

36 Allaire PD, Marat AL, Dall'Armi C, Di Paolo G, McPherson PS, Ritter B. The Connecdenn DENN domain: a GEF for Rab35 mediating cargo-specific exit from early endosomes. Mol Cell 2010;37:370-82.
37 Marat AL, Dokainish H, McPherson PS. DENN domain proteins: regulators of Rab GTPases. J Biol Chem 2011:286:13791-800.

38 Ciura S, Lattante S, Le Ber I, Latouche M, Tostivint H, Brice A, Kabashi E. Loss of function of C9orf72 causes motor deficits in a zebrafish model of amyotrophic lateral sclerosis. Ann Neurol 2013;74:180-7.

39 Xiao S, MacNair L, McGoldrick P, McKeever PM, McLean JR, Zhang M, Keith J, Zinman L, Rogaeva E, Robertson J. Isoform-specific antibodies reveal distinct subcellular localizations of C9orf72 in amyotrophic lateral sclerosis. Ann Neurol 2015;78:568-83

40 Burberry A, Suzuki N, Wang JY, Moccia R, Mordes DA, Stewart MH, Suzuki-Uematsu S, Ghosh S, Singh A, Merkle FT, Koszka K, Li QZ, Zon L, Rossi DJ, Trowbridge JJ, Notarangelo LD, Eggan K. Loss-of-function mutations in the C90RF72 mouse ortholog cause fatal autoimmune disease. Sci Trans/ Med 2016;8:347ra93.

41 Hammond SM, Wood MJ. Genetic therapies for RNA mis-splicing diseases. Trends Genet 2011;27:196-205.

42 Scotti MM, Swanson MS. RNA mis-splicing in disease. Nat Rev Genet 2016;17:19-32.

43 Prudencio M, Belzil VV, Batra R, Ross CA, Gendron TF, Pregent LJ, Murray ME, Overstreet KK, Piazza-Johnston AE, Desaro P, Bieniek KF, DeTure M, Lee WC, Biendarra SM, Davis MD, Baker MC, Perkerson RB, van Blitterswijk M, Stetler CT, Rademakers R, Link CD, Dickson DW, Boylan KB, Li H, Petrucelli L. Distinct brain transcriptome profiles in C9orf72-associated and sporadic ALS. Nat Neurosci 2015;18:1175-82.

44 Zu T, Gibbens B, Doty NS, Gomes-Pereira M, Huguet A, Stone MD, Margolis J, Peterson M, Markowski TW, Ingram MA, Nan Z, Forster C, Low WC, Schoser B, Somia NV, Clark HB, Schmechel S, Bitterman PB, Gourdon G, Swanson MS, Moseley M, Ranum LP. Non-ATG-initiated translation directed by microsatellite expansions. Proc Natl Acad Sci USA 2011;108:260-5.

45 Lagier-Tourenne C, Baughn M, Rigo F, Sun S, Liu P, Li HR, Jiang J, Watt AT, Chun S, Katz M, Qiu J, Sun Y, Ling SC, Zhu Q, Polymenidou M, Drenner K, Artates JW, McAlonis-Downes M, Markmiller S, Hutt KR, Pizzo DP, Cady J, Harms MB, Baloh RH, Vandenberg SR, Yeo GW, Fu XD, Bennett CF, Cleveland DW, Ravits J. Targeted degradation of sense and antisense C9orf72 RNA foci as therapy for ALS and frontotemporal degeneration. Proc Natl Acad Sci USA 2013;110:E4530-9.

46 Mizielinska S, Lashley T, Norona FE, Clayton EL, Ridler CE, Fratta P, Isaacs AM. C9orf72 frontotemporal lobar degeneration is characterised by frequent neuronal sense and antisense RNA foci. Acta Neuropathol 2013;126:845-57.

47 Zu T, Liu Y, Bañez-Coronel M, Reid T, Pletnikova O, Lewis J, Miller TM, Harms MB, Falchook AE, Subramony SH, Ostrow LW, Rothstein JD, Troncoso JC, Ranum LP. RAN proteins and RNA foci from antisense transcripts in C9ORF72 ALS and frontotemporal dementia. Proc Natl Acad Sci USA 2013;110:E4968-77.

48 Lee YB, Chen HJ, Peres JN, Gomez-Deza J, Attig J, Stalekar M, Troakes C, Nishimura AL, Scotter EL, Vance C, Adachi Y, Sardone V, Miller JW, Smith BN, Gallo JM, Ule J, Hirth F, Rogelj B, Houart C, Shaw CE. Hexanucleotide repeats in ALS/FTD form length-dependent RNA foci, sequester RNA binding proteins, and are neurotoxic. Cell Rep 2013;5:1178-86.

49 Davidson YS, Barker H, Robinson AC, Thompson JC, Harris J, Troakes C, Smith B, Al-Saraj S, Shaw C, Rollinson S, Masuda-Suzukake M, Hasegawa M, Pickering-Brown S, Snowden JS, Mann DM. Brain distribution of dipeptide repeat proteins in frontotemporal lobar degeneration and motor neurone disease associated with expansions in C9ORF72. Acta Neuropathol Commun 2014;2:70.

50 Haeusler AR, Donnelly CJ, Rothstein JD. The expanding biology of the C9orf72 nucleotide repeat expansion in neurodegenerative disease. Nat Rev Neurosci 2016;17:383-95.

51 Jovičić A, Mertens J, Boeynaems S, Bogaert E, Chai N, Yamada SB, Paul JW Jr, Sun S, Herdy JR, Bieri G, Kramer NJ, Gage FH, Van Den Bosch L, Robberecht W, Gitler AD. Modifiers of C9orf72 dipeptide repeat toxicity connect nucleocytoplasmic transport defects to FTD/ALS. Nat Neurosci 2015;18:1226-9.

52 Mizielinska S, Grönke S, Niccoli T, Ridler CE, Clayton EL, Devoy A, Moens T, Norona FE, Woollacott IO, Pietrzyk J, Cleverley K, Nicoll AJ, Pickering-Brown S, Dols J, Cabecinha M, Hendrich O, Fratta P, Fisher EM, Partridge L, Isaacs AM. C9orf72 repeat expansions cause neurodegeneration in Drosophila through arginine-rich proteins. Science 2014;345:1192-4.

53 Tran H, Almeida S, Moore J, Gendron TF, Chalasani U, Lu Y, Du X, Nickerson JA, Petrucelli L, Weng Z, Gao FB. Differential toxicity of nuclear RNA foci versus dipeptide repeat proteins in a Drosophila model of C9ORF72 FTD/ALS. Neuron 2015;87:1207-14.

54 Kwon I, Xiang S, Kato M, Wu L, Theodoropoulos P, Wang T, Kim J, Yun J, Xie Y, McKnight SL. Poly-dipeptides encoded by the C9orf72 repeats bind nucleoli, impede RNA biogenesis, and kill cells. Science 2014;345:1139-45.

55 O'Rourke JG, Bogdanik L, Muhammad AK, Gendron TF, Kim KJ, Austin A, Cady J, Liu EY, Zarrow J, Grant S, Ho R, Bell S, Carmona S, Simpkinson M, Lall D, Wu K, Daughrity L, Dickson DW, Harms MB, Petrucelli L, Lee EB, Lutz CM, Baloh RH. C9orf72 BAC transgenic mice display typical pathologic features of ALS/FTD. Neuron 2015;88:892-901.

56 Zhang K, Donnelly CJ, Haeusler AR, Grima JC, Machamer JB, Steinwald P, Daley EL, Miller SJ, Cunningham KM, Vidensky S, Gupta S, Thomas MA, Hong I, Chiu SL, 
Huganir RL, Ostrow LW, Matunis MJ, Wang J, Sattler R, Lloyd TE, Rothstein JD. The C9orf72 repeat expansion disrupts nucleocytoplasmic transport. Nature 2015;525:56-61.

57 Freibaum BD, Lu Y, Lopez-Gonzalez R, Kim NC, Almeida S, Lee KH, Badders N, Valentine M, Miller BL, Wong PC, Petrucelli L, Kim HJ, Gao FB, Taylor JP. GGGGCC repeat expansion in C9orf72 compromises nucleocytoplasmic transport. Nature 2015;525:129-33.

58 Gitcho MA, Baloh RH, Chakraverty S, Mayo K, Norton JB, Levitch D, Hatanpaa KJ, White CL III, Bigio EH, Caselli R, Baker M, Al-Lozi MT, Morris JC, Pestronk A, Rademakers R, Goate AM, Cairns NJ. TDP-43 A315T mutation in familial motor neuron disease. Ann Neurol 2008;63:535-8.

59 Kabashi E, Valdmanis PN, Dion P, Spiegelman D, McConkey BJ, Vande Velde C, Bouchard JP, Lacomblez L, Pochigaeva K, Salachas F, Pradat PF, Camu W, Meininger V, Dupre N, Rouleau GA. TARDBP mutations in individuals with sporadic and familial amyotrophic lateral sclerosis. Nat Genet 2008;40:572-4.

60 Sreedharan J, Blair IP, Tripathi VB, Hu X, Vance C, Rogelj B, Ackerley S, Durnall JC, Williams KL, Buratti E, Baralle F, de Belleroche J, Mitchell JD, Leigh PN, Al-Chalabi A, Miller CC, Nicholson G, Shaw CE. TDP-43 mutations in familial and sporadic amyotrophic lateral sclerosis. Science 2008;319:1668-72.

61 Ling SC, Polymenidou M, Cleveland DW. Converging mechanisms in ALS and FTD: disrupted RNA and protein homeostasis. Neuron 2013;79:416-38.

62 Lee EB, Lee VM, Trojanowski JQ. Gains or losses: molecular mechanisms of TDP43-mediated neurodegeneration. Nat Rev Neurosci 2012;13:38-50.

63 Woerner AC, Frottin F, Hornburg D, Feng LR, Meissner F, Patra M, Tatzelt J, Mann M, Winklhofer KF, Hartl FU, Hipp MS. Cytoplasmic protein aggregates interfere with nucleocytoplasmic transport of protein and RNA. Science 2016;351:173-6.

64 Kwiatkowski TJ Jr, Bosco DA, Leclerc AL, Tamrazian E, Vanderburg CR, Russ C, Davis A, Gilchrist J, Kasarskis EJ, Munsat T, Valdmanis P, Rouleau GA, Hosler BA, Cortelli P, de Jong PJ, Yoshinaga Y, Haines JL, Pericak-Vance MA, Yan J, Ticozzi N, Siddique T, McKenna-Yasek D, Sapp PC, Horvitz HR, Landers JE, Brown RH Jr. Mutations in the FUS/TLS gene on chromosome 16 cause familial amyotrophic lateral sclerosis. Science 2009;323:1205-8.

65 Vance C, Rogelj B, Hortobágyi T, De Vos KJ, Nishimura AL, Sreedharan J, Hu X, Smith B, Ruddy D, Wright P, Ganesalingam J, Williams KL, Tripathi V, Al-Saraj S, Al-Chalabi A, Leigh PN, Blair IP, Nicholson G, de Belleroche J, Gallo JM, Miller CC, Shaw CE. Mutations in FUS, an RNA processing protein, cause familial amyotrophic lateral sclerosis type 6. Science 2009;323:1208-11.

66 Colombrita C, Onesto E, Megiorni F, Pizzuti A, Baralle FE, Buratti E, Silani V, Ratti A. TDP-43 and FUS RNA-binding proteins bind distinct sets of cytoplasmic messenger RNAs and differently regulate their post-transcriptional fate in motoneuron-like cells. J Biol Chem 2012;287:15635-47.

67 Dormann D, Haass C. TDP-43 and FUS: a nuclear affair. Trends Neurosci 2011;34:339-48.

68 DeJesus-Hernandez M, Desaro P, Johnston A, Ross OA, Wszolek ZK, Ertekin-Taner N Graff-Radford NR, Rademakers R, Boylan K. Novel p.lle151Val mutation in VCP in a patient of African American descent with sporadic ALS. Neurology 2011;77:1102-3.

69 Johnson JO, Mandrioli J, Benatar M, Abramzon Y, Van Deerlin VM, Trojanowski JQ, Gibbs JR, Brunetti M, Gronka S, Wuu J, Ding J, McCluskey L, Martinez-Lage M, Falcone D, Hernandez DG, Arepalli S, Chong S, Schymick JC, Rothstein J, Landi F, Wang YD, Calvo A, Mora G, Sabatelli M, Monsurrò MR, Battistini S, Salvi F, Spataro
R, Sola P, Borghero G; ITALSGEN Consortium, Galassi G, Scholz SW, Taylor JP, Restagno G, Chiò A, Traynor BJ. Exome sequencing reveals VCP mutations as a cause of familial ALS. Neuron 2010;68:857-64.

70 Deng HX, Chen W, Hong ST, Boycott KM, Gorrie GH, Siddique N, Yang Y, Fecto F, Shi Y, Zhai H, Jiang H, Hirano M, Rampersaud E, Jansen GH, Donkervoort S, Bigio EH, Brooks BR, Ajroud K, Sufit RL, Haines JL, Mugnaini E, Pericak-Vance MA, Siddique T. Mutations in UBQLN2 cause dominant X-linked juvenile and adult-onset ALS and ALS/dementia. Nature 2011;477:211-5.

71 Fecto F, Yan J, Vemula SP, Liu E, Yang Y, Chen W, Zheng JG, Shi Y, Siddique N, Arrat H, Donkervoort S, Ajroud-Driss S, Sufit RL, Heller SL, Deng HX, Siddique T. SQSTM1 mutations in familial and sporadic amyotrophic lateral sclerosis. Arch Neurol 2011;68:1440-6.

72 Rubino E, Rainero I, Chiò A, Rogaeva E, Galimberti D, Fenoglio P, Grinberg Y, Isaia G, Calvo A, Gentile S, Bruni AC, St George-Hyslop PH, Scarpini E, Gallone S, Pinessi L, TODEM Study Group. SQSTM1 mutations in frontotemporal lobar degeneration and amyotrophic lateral sclerosis. Neurology 2012;79:1556-62.

73 Liu Y, Yu JT, Sun FR, Ou JR, Qu SB, Tan L. The clinical and pathological phenotypes of frontotemporal dementia with C9ORF72 mutations. J Neurol Sci 2013:335:26-35.

74 Cady J, Allred P, Bali T, Pestronk A, Goate A, Miller TM, Mitra RD, Ravits J, Harms $\mathrm{MB}$, Baloh RH. Amyotrophic lateral sclerosis onset is influenced by the burden of rare variants in known amyotrophic lateral sclerosis genes. Ann Neurol 2015;77:100-13.

75 Renton AE, Chiò A, Traynor BJ. State of play in amyotrophic lateral sclerosis genetics. Nat Neurosci 2014;17:17-23.

76 Gros-Louis F, Soucy G, Larivière R, Julien JP. Intracerebroventricular infusion of monoclonal antibody or its derived Fab fragment against misfolded forms of SOD1 mutant delays mortality in a mouse model of ALS. J Neurochem 2010;113:1188-99.

77 Wheeler TM, Leger AJ, Pandey SK, MacLeod AR, Nakamori M, Cheng SH, Wentworth BM, Bennett CF, Thornton CA. Targeting nuclear RNA for in vivo correction of myotonic dystrophy. Nature 2012;488:111-15.

78 Miller TM, Pestronk A, David W, Rothstein J, Simpson E, Appel SH, Andres PL, Mahoney K, Allred P, Alexander K, Ostrow LW, Schoenfeld D, Macklin EA, Norris DA, Manousakis G, Crisp M, Smith R, Bennett CF, Bishop KM, Cudkowicz ME. An antisense oligonucleotide against SOD1 delivered intrathecally for patients with SOD1 familial amyotrophic lateral sclerosis: a phase 1, randomised, first-in-man study. Lancet Neurol 2013;12:435-42.

79 Yang WY, Wilson HD, Velagapudi SP, Disney MD. Inhibition of non-ATG translational events in cells via covalent small molecules targeting RNA. J Am Chem Soc 2015;137:5336-45.

80 Zamiri B, Reddy K, Macgregor RB Jr, Pearson CE. TMPyP4 porphyrin distorts RNA G-quadruplex structures of the disease-associated $\mathrm{r}(\mathrm{GGGGCC})$ n repeat of the C9orf72 gene and blocks interaction of RNA-binding proteins. J Biol Chem 2014;289:4653-9.

81 Dimos JT, Rodolfa KT, Niakan KK, Weisenthal LM, Mitsumoto H, Chung W, Croft GF, Saphier G, Leibel R, Goland R, Wichterle H, Henderson CE, Eggan K. Induced pluripotent stem cells generated from patients with ALS can be differentiated into motor neurons. Science 2008;321:1218-21. 